研 究

\title{
ソフトプロセスによる新規ビスマス塩基性硝酸塩複合酸化物の合成(I) $-\mathrm{BiO}\left(\mathrm{NO}_{3}\right)-\mathrm{KOH}-\mathrm{H}_{2} \mathrm{O}$ 系 -
}

\author{
西尾 友志 ${ }^{2}$, 雨澤 浩史 ${ }^{4}$, 堀部 正吉放, 山本 直一个1 \\ 41 京都大学大学院・人間・環境学研究科, $\overline{7}$ 606-8501 京都市左京区吉田二本松町. \\ 的京都大学総合人間学部, $=$ 606-8501 京都市左京区吉田二本松町.
}

\section{The Synthesis of New Bismuth Basic Nitrate Complex Oxides by the Soft Processing $-\mathrm{BiO}\left(\mathrm{NO}_{3}\right)-\mathrm{KOH}-\mathrm{H}_{2} \mathrm{O}$ System-}

\author{
Yuji Nishio ${ }^{\text {th }}$, Koji Amezawa ${ }^{\text {h1 }}$ Masayoshi Horibe ${ }^{\hbar 2}$ and Naoichi Yamamoto ${ }^{\text {t1 }}$ \\ ${ }^{41}$ Graduate School of Human and Environmental Studies, Kyoto University, Yoshida-nihonmatsucho, Sakyo-ku, Kyoto, 606-8501. \\ $\hbar^{2}$ Faculty of Integrated Human Studies, Kyoto University, Yoshida-nihonmatsucho, Sakyo-ku, Kyoto 606-8501.
}

Received March 1, 2002

\section{SYNOPSIS}

The formation diagram of $\mathrm{BiO}\left(\mathrm{NO}_{3}\right)-\mathrm{KOH}-\mathrm{H}_{2} \mathrm{O}$ system was studied using hydrothermal or "wet" method. New seven kinds of compounds of bismuth basic nitrate complex oxides were detected by XRD measurements. The four of new compounds were separated as single phases and the chemical compositions were determined to be $\mathrm{Bi}_{5}\left(\mathrm{NO}_{3}\right)_{2} \mathrm{O}_{6}(\mathrm{OH}), \mathrm{Bi}_{5}\left(\mathrm{NO}_{3}\right) \mathrm{O}_{6}(\mathrm{OH})_{2}, \mathrm{Bi}_{6}\left(\mathrm{NO}_{3}\right)_{3} \mathrm{O}_{7}(\mathrm{OH})$ and $\mathrm{Bi}_{6}\left(\mathrm{NO}_{3}\right)_{2} \mathrm{O}_{7}(\mathrm{OH})_{2}$, respectively. The effects of the temperature and $\mathrm{pH}$ value on the composition of the compounds were also speculated.

KEYWORDS

$\mathrm{Bi}_{5}\left(\mathrm{NO}_{3}\right)_{2} \mathrm{O}_{6}(\mathrm{OH}), \mathrm{Bi}_{5}\left(\mathrm{NO}_{3}\right) \mathrm{O}_{6}(\mathrm{OH})_{2}, \mathrm{i}_{6}\left(\mathrm{NO}_{3}\right)_{3} \mathrm{O}_{7}(\mathrm{OH}), \mathrm{Bi}_{6}\left(\mathrm{NO}_{3}\right)_{2} \mathrm{O}_{7}(\mathrm{OH})_{2}$, new bismuth basic nitrate complex oxides

\section{1 緒 言}

ビスマス塩基性硝酸塩複合酸化物は多くの種類があるとさ れ，古くから薬用をはじめ多方面で使用されてきた. ビスマ 又塩基性硝酸塩複合酸化物の中に含まれる $\mathrm{NO}_{3}{ }^{- \text {基は水溶液中 }}$ のハロゲンイオン $\left(\mathrm{X}^{-}\right)$と強い交换性を示すことが知られてい た.この特性は近年, 原子炉から排出される極めて長い半減 期を持つ放射性 $\mathrm{I}^{-}$の水溶液からの抽出および固定唷として注 目され，研究が進められて来ている. 例えば P.S. Anand and D. R. Baxi ${ }^{2)}$, P.Taylar et $\mathrm{al}^{2)}$, H. Kodama ${ }^{3-5)}$ 等により $\alpha-\mathrm{Bi}_{2} \mathrm{O}_{3}$, $\mathrm{Bi}_{5} \mathrm{O}_{7}\left(\mathrm{NO}_{3}\right), \mathrm{BiO}\left(\mathrm{NO}_{3}\right) \cdot 0.5 \mathrm{H}_{2} \mathrm{O}$ 等の特性が報告されている.こ れらのヒススマス塩基性硝酸塩複合酸化物は，しかしながら， 固体化学の観点からすれば現時点では生成条件, 化学組成, 結晶構造等の基本的性質について正確なキャラクタリゼー ションが行われているとは言い難く，したがってキャラクタ リゼーションに立脚したより定量的な機能特性の評価はおこ なわれていないと考えられる。

本研究はヒスマス塩基性硝酸塩複合酸化物の種類とその生成 条件をより正確にするために, $\mathrm{BiO}\left(\mathrm{NO}_{3}\right)$ を出発原料として用 い,ソフトプロッセシングの一種である水熱合成条件下での 実験結果を報告している。

\section{2 実験方法}

\section{1 合成方法}

出発原料として用いた $\mathrm{BiO}\left(\mathrm{NO}_{3}\right)$ は水溶液からの直接合成反 応を用いて生成したの. 合成方法は以下の様である.ガラスア ンプル (内容積 $280 \mathrm{ml}$ )に Bi( $\left(\mathrm{NO}_{3}\right)_{3} \cdot 5 \mathrm{H}_{2} \mathrm{O}$ の $0.0467 \mathrm{~mol}$ を $\mathrm{H}_{2} \mathrm{O}$ $154 \mathrm{ml}$ と共に入れて溶封し，これを振とう式恒温槽に入れて， 反応温度 $=85^{\circ} \mathrm{C}$, 反応時間 $=24 \mathrm{~h}$, 振とう速度 $120 \mathrm{rpm}$ の条件 下に保持し, 得られた沈殿をろ過, 水洗後にXRD 測定より $\mathrm{BiO}\left(\mathrm{NO}_{3}\right)$ の単相であることを確認して原料とした. $\mathrm{KOH}$ その 他の試薬は市販の特級試薬を用いた。

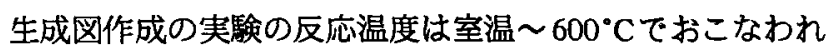
た. 反応温度範囲により 3 種類の異った形式の反応容器を用 いた. 異なった様式の反応容器を用いた最大の理由は，与え られた温度条件下で発生する平衡圧を容器内に封じ込めるた めの技術上の要求によるものである．以下では便宜上 250 $600^{\circ} \mathrm{C}$ を高温領域, $100 \sim 300^{\circ} \mathrm{C}$ を中温領域, 室温〜 $100^{\circ} \mathrm{C}$ を 低温領域と記述している.

高温領域; 出発原料の $\mathrm{BiO}\left(\mathrm{NO}_{3}\right)$ の $0.2 \mathrm{mmol}$ を所定の濃度の $\mathrm{KOH}$ 水溶波 $0.33 \mathrm{~m} l$ と共に金 $($ 或いは銀 $)$ チューフ $(5 \phi \times 60 \mathrm{~mm})$ に溶封した.これをテストチューブ型オートクレーブに挿入 
し, 反応時間 $=36 \mathrm{~h}$, 圧力 $=100 \mathrm{Mpa}$, 反応温度 $=250 \sim 600^{\circ} \mathrm{C}$ の所定の温度で保持した. 反応後オートクレーブを室温まで 急冷し，金チューブより取り出した.

中温領域 $; 5.0 \mathrm{mmol} の \mathrm{BiO}\left(\mathrm{NO}_{3}\right)$ を所定の濃度の $\mathrm{KOH}$ 水溶 液 $33 \mathrm{~m} l$ と共にテフロン容器に入れた.このテフロン容器を モーレ一型オートクレーブに抻入し, 反応時間 $=36 \mathrm{~h}$, 反応温 度 $=100 \sim 300^{\circ} \mathrm{C}$ 所定の温度で保持した. なお圧力は平衡自 然圧である. 反応後オートクレーブを室温まで徐冷した後， 生成物をテフロン容器より取り出した。

低温領域; $5.0 \mathrm{mmol}$ の $\mathrm{BiO}\left(\mathrm{NO}_{3}\right)$ を所定の濃度の $\mathrm{KOH}$ 水溶 液 $33 \mathrm{~m} l$ と共にテフロン容器に入れ, このテフロン容器を恒温 振とう槽に浸して, 反応時間 $=5 \mathrm{~h}$, 反応温度 $=$ 室温 $80^{\circ} \mathrm{C} て ゙$ 保持した.

上記のいずれの反応温度領域でも, 反応温度後の容器内に は沈殿物と上澄み液が存在した，沈殿物は吸引，万過して乾 燥後, XRDによる相同定とSEMによる粒形観察を行った。 ま た同時に反応後の上澄み液の $\mathrm{pH}$ を測定した.

\section{2 化学組成分析}

ビスマスの定量(逆キレート滴定); 試料を約 $40 \mathrm{mg}$ を精密に 計りとり, 䀼硝酸 $1 \mathrm{ml}$ を加えて溶解させ, $0.01 \mathrm{~mol} / l$ EDTA溶 液 $30 \mathrm{~m} l$ を加え涅和した後, この溶液を $0.01 \mathrm{~mol} / l$ の $\mathrm{NaOH}$ 水 溶液を用いて $\mathrm{pH}=2.3$ に調整した. 次に $\mathrm{pH}=2.3$ を保ちながら $0.01 \mathrm{~mol} / /$ 硝酸ヒススス水溶液で滴定した。同時に空試験を行 い補正した。なお，指示薬はXO指示薬を用いた。

陰イオンおよび陽イオンの定量(イオンクロマトグラフ法); 試料の約 $200 \mathrm{mg}$ を $100 \mathrm{ml}$ のメスフラスコに計り取り，蒸留水 約 $10 \mathrm{~m} l$ を加えて分散し, 次いで 60\%過塩素酸 $1.5 \mathrm{~m} l$ を正確に 加元，超音波洗浄機で約 15 分間分散し冷却後，更に約 15 分間

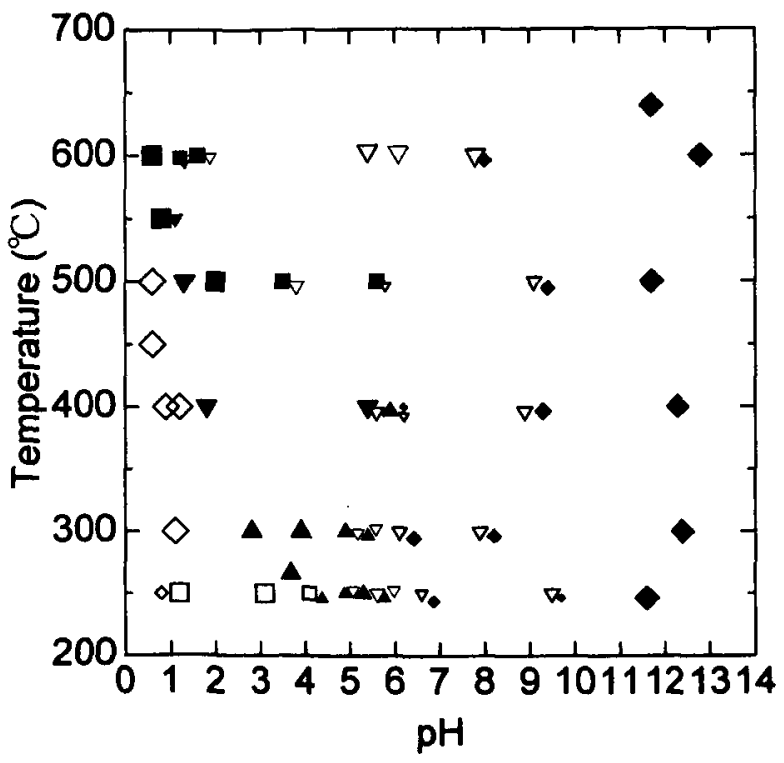

Fig.1 Formation diagram of the precipitate obtained in $\mathrm{BiO}\left(\mathrm{NO}_{3}\right)$ $\mathrm{KOH}-\mathrm{H}_{2} \mathrm{O}$ system at temperature of 250 to $600^{\circ} \mathrm{C}$. $\nabla$ : new compound "A" $\left(\mathrm{Bi}_{5}\left(\mathrm{NO}_{3}\right)_{2} \mathrm{O}_{6}(\mathrm{OH})\right), \nabla:$ new compound "B" $\left(\mathrm{Bi}_{5}\left(\mathrm{NO}_{3}\right) \mathrm{O}_{6}(\mathrm{OH})_{2}\right), \diamond$ : new compound "C" $\left(\mathrm{Bi}_{6}\left(\mathrm{NO}_{3}\right)_{3} \mathrm{O}_{4}(\mathrm{OH})_{3}\right)$, : new compound " $\mathrm{D}^{\prime}, \boldsymbol{\Delta}$ : new compound " $\mathrm{E}$ " $\left(\mathrm{Bi}_{6}\left(\mathrm{NO}_{3}\right)_{2} \mathrm{O}_{7}(\mathrm{OH})_{2}\right), \quad \alpha-\mathrm{Bi}_{2} \mathrm{O}_{3}, \square: \mathrm{Bi}_{6}\left(\mathrm{NO}_{3}\right)_{3} \mathrm{O}_{6}(\mathrm{OH})_{3}$.
分散し,この操作を4〜7回繰り返し完全に溶解させた.これに 蒸留水を加えて正確に $100 \mathrm{~m} l$ とし，擋汼均一にした液の $5 \mathrm{~m} l$ を正確に $100 \mathrm{~m} l$ のメスフラスコに計りとり，蒸留水を加えて $100 \mathrm{ml}$ とし試料溶液とした。標準溶液はイオンクロマトグラ フ用の各 $1000 \mathrm{ppm}$ の標準溶液 (和光純薬样) を蒸留水で所定 の濃度に希积して使用した。測定装置にはイオンクロマトク ラフ (IC-500P 横河電気㴊)を使用した。陰イオン分析には分 離カラムとして, IC-Anion-PW (東ソ一-泚), 溶離液には $1 \mathrm{mM}$ $\mathrm{Na}_{2} \mathrm{CO}_{3}$ と $3 \mathrm{mM} \mathrm{NaHCO}$ をもちいた。 また除去液には $15 \mathrm{mM}$ $\mathrm{H}_{2} \mathrm{SO}_{4}$ を使用した。 陽イオン分析には分離カラムにIC-/Cation (東ソ一俶)，溶離液には $2 \mathrm{mM} \mathrm{HNO}_{3}$ を使用した。

\section{3 結果およひ考察}

\section{1 生成図}

高温領域; Fig.1に反応温度と反応後のpHをパラメーターと した生成図を示す.この結果から反応温度 $=400 \sim 500^{\circ} \mathrm{C}, \mathrm{pH}=$ $1.5 \sim 2$ で化合物 $\mathrm{A}$, 反応温度 $=\sim 600^{\circ} \mathrm{C}, \mathrm{pH}=5 \sim 6$ で化合物 $\mathrm{B}$, 反応温度 $=300 \sim 500^{\circ} \mathrm{C}, \mathrm{pH}=\sim 1$ で化合物 $\mathrm{C}$, 反応温度 $=$ $500 \sim 600^{\circ} \mathrm{C}, \mathrm{pH}=\sim 1$ で化合物 $\mathrm{D}$, 反応温度 $=270 \sim 300^{\circ} \mathrm{C}$, $\mathrm{pH}=3 \sim 4$ で化合物 $\mathrm{E}$ ，の生成が見られた ${ }^{* 1}$ 。

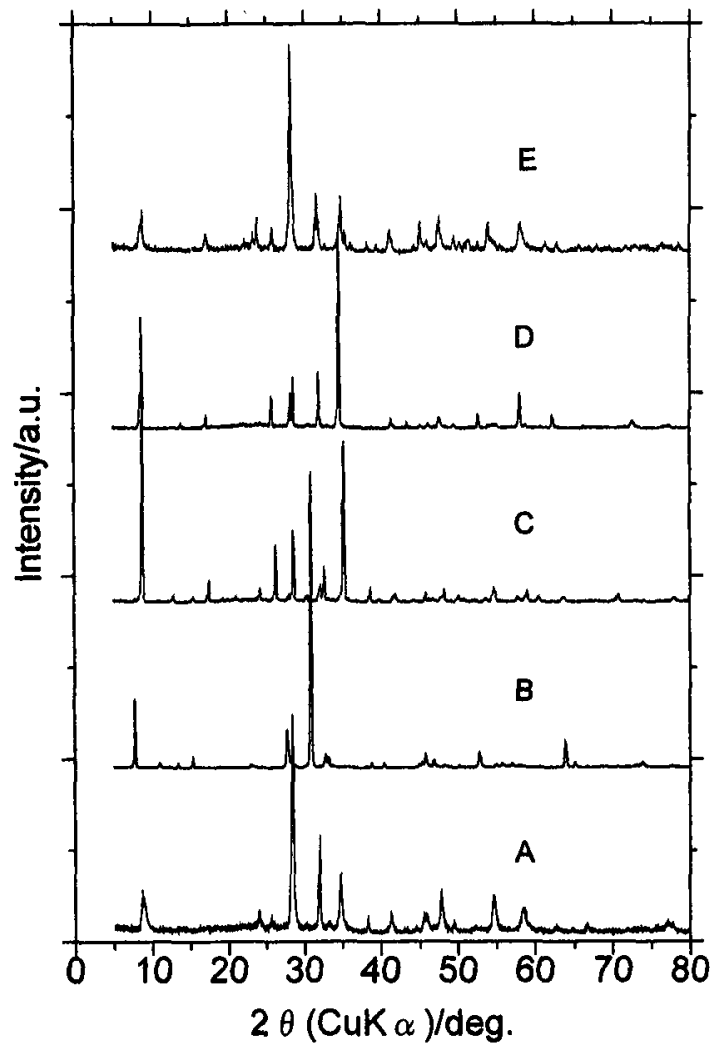

Fig.2 XRD patterns of new compounds ("A" "E").

\footnotetext{
•1) 化合物A〜Eと記载されている化合物のXRDバターンはいずれもこれまて に報告されておらず新覞化合物と考えられる。これらの新梘化合物の組成 分析結果は後の“化学組成” の章に記载されているか，全ての图の説明に は決定された組成を $\mathrm{A} \sim \mathrm{C}, \mathrm{E}$ の後の（）の中に記している．また化合物 $\mathrm{B}$ は Kodama 等により報告された化合物の $\mathrm{Bi}_{9} \mathrm{O}_{-}\left(\mathrm{NO}_{3}\right)$ と極めて類似した XRD バターンを与えるク。しかしながら，後に報告する化学組成が完全に一致し ていないため，ここては別種の化合物と表記している。
} 


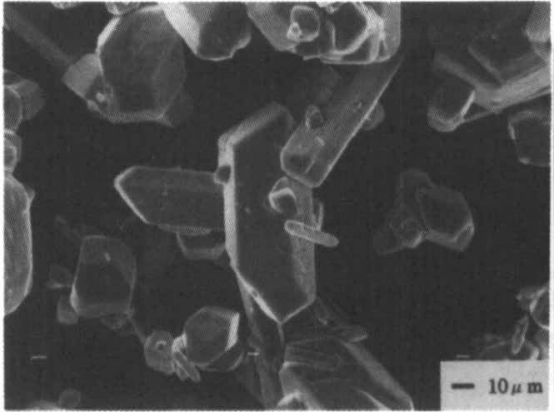

(a)

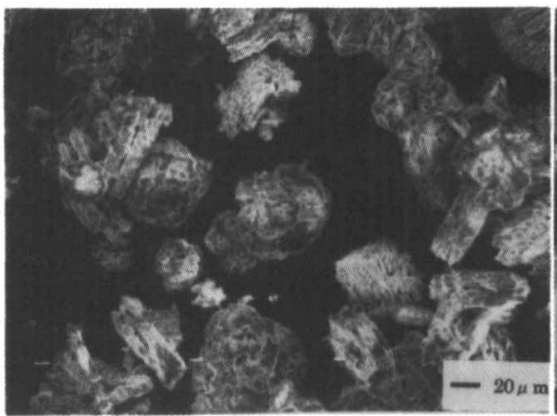

(d)

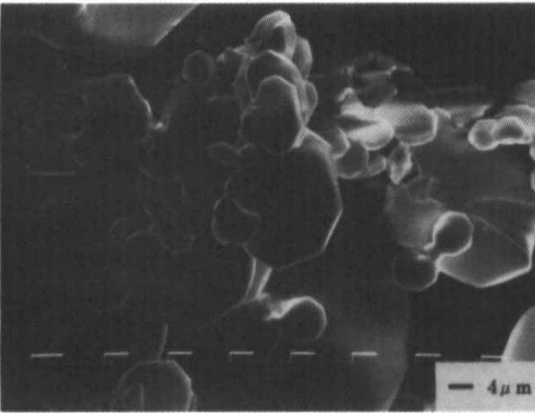

(b)

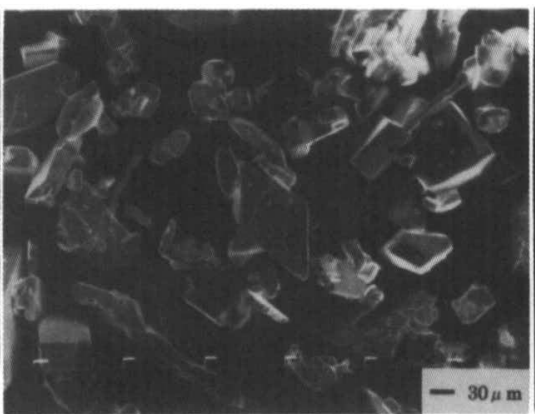

(e)

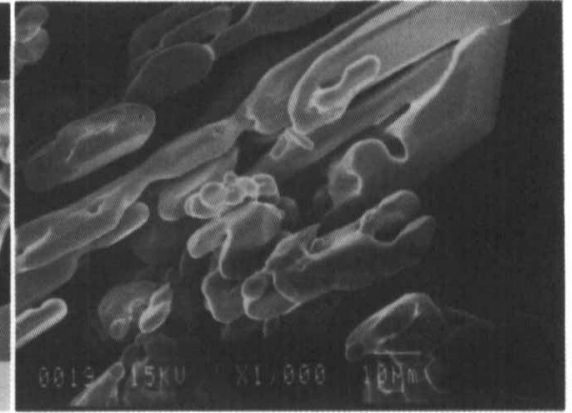

(c)

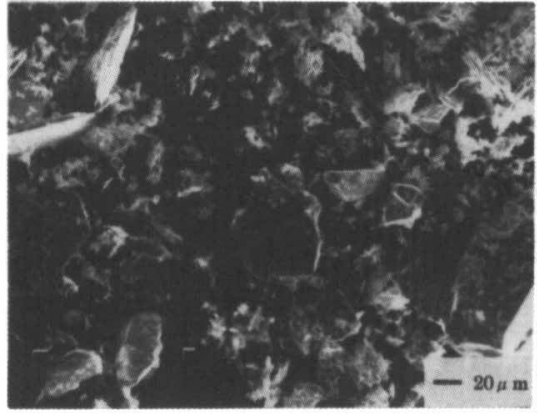

(g)

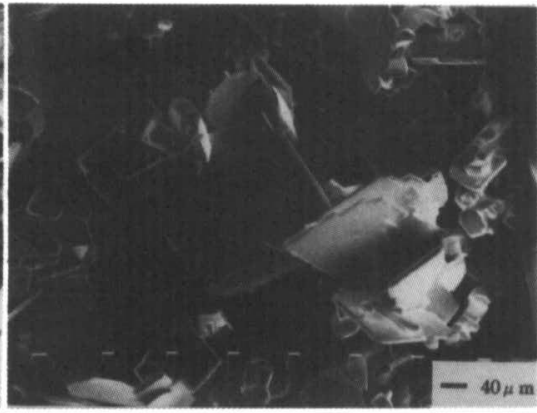

(h)

Fig.3 SEM image of the obtained compounds (a) $\mathrm{BiO}\left(\mathrm{NO}_{3}\right)$ (starting material), (b) $\mathrm{Bi}_{6}\left(\mathrm{NO}_{3}\right)_{3} \mathrm{O}_{6}(\mathrm{OH})_{3}$, (c) $\alpha-\mathrm{Bi}_{2} \mathrm{O}_{3}$, (d) new compound "A" $\left(\mathrm{Bi}_{5}\left(\mathrm{NO}_{3}\right)_{2} \mathrm{O}_{6}(\mathrm{OH})\right.$ ), (e) new compound "B" $\left(\mathrm{Bi}_{5}\left(\mathrm{NO}_{3}\right) \mathrm{O}_{6}(\mathrm{OH})_{2}\right)$, (f) new compound "C" $\left(\mathrm{Bi}_{6}\left(\mathrm{NO}_{3}\right)_{3} \mathrm{O}_{7}(\mathrm{OH})_{3}\right)$, (g) new compound "D", (h) new compound " $\mathrm{E} "\left(\mathrm{Bi}_{6}\left(\mathrm{NO}_{3}\right)_{2} \mathrm{O}_{7}(\mathrm{OH})_{2}\right)$.

また反応温度 $=\sim 250^{\circ} \mathrm{C}, \mathrm{pH}=3 \sim 4$ で $\mathrm{Bi}_{6}\left(\mathrm{NO}_{3}\right)_{3} \mathrm{O}_{6}(\mathrm{OH})_{3}$ か⿱ 生成し, $\mathrm{pH}=11$ 以上のアルカリ性側では温度にかかわらず $\alpha-\mathrm{Bi}_{2} \mathrm{O}_{3}$ が生成した. Fig.2に化合物 $\mathrm{A} \sim \mathrm{E}$ の XRDパターンを 示す. 化合物 $\mathrm{A}$ は薄黄色を，その他の化合物は白色を示して いる.これらの化合物 $\mathrm{A} \sim \mathrm{E}$ および出発原料の $\mathrm{BiO}\left(\mathrm{NO}_{3}\right)$ およ び $\mathrm{Bi}_{6}\left(\mathrm{NO}_{3}\right)_{3} \mathrm{O}_{6}(\mathrm{OH})_{3}, \alpha-\mathrm{Bi}_{2} \mathrm{O}_{3}$ のSEM写真を Fig.3に示す.これ らの化合物の粒子は出発原料の $\mathrm{BiO}\left(\mathrm{NO}_{3}\right)$ とは異なったそれぞ れ特有の形をもつ事が示されている.

中温領域; Fig. 4,5 に温度範囲を $200 \sim 300^{\circ} \mathrm{C}$ と $100 \sim 180^{\circ} \mathrm{C}$

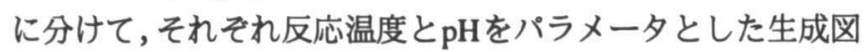
を示す. 反応温度 $=280 \sim 300^{\circ} \mathrm{C}, \mathrm{pH}=2 \sim 3$ 付近で化合物 $\mathrm{A} の$ 単一相がまた反応温度 $=\sim 260^{\circ} \mathrm{C}, \mathrm{pH}=4 \sim 5$ で化合物 $\mathrm{E}$ の単 一相が生成している.また同一化合物では反応温度が高くな るにつれて生成領域が酸性側に移行することが判明した.
低温領域; Fig.6に温度範囲が室温 $100^{\circ} \mathrm{C}$ の生成図を高温， 中温領域と同じパラメータ表示で示す.この温度範囲は出発 原料の $\mathrm{BiO}\left(\mathrm{NO}_{3}\right)$ の合成温度よりも低温に相当する.この温度 領域では, 新らたに 3 種類の従来報告されていない XRD パ ターンを示す新規化合物F, Gおよび結晶性の低いブロードな $\mathrm{XRD}$ パターンを示す化合物が生成した. 新規化合物 $F, G$ は, $\mathrm{BiO}\left(\mathrm{NO}_{3}\right)$ を出発原料とした現在の反応系では結晶性の低い化 合物が常に混合物として生成し, 単離することが困難である が, 系を $\alpha-\mathrm{Bi}_{2} \mathrm{O}_{3}-\mathrm{HNO}_{3}-\mathrm{H}_{2} \mathrm{O}$ に変更することにより, この化 合物の生成を押さえることにより比較的容易に単離可能であ る"2).

-2) 生成条件の子細,化学組成等は次論文を参照: ソフトプロセスによる新規ヒ スマス塩基性硝酸堨被合酸化物の合成(II)- $\alpha-\mathrm{Bi}_{2} \mathrm{O}_{3}-\mathrm{HNO}_{3}-\mathrm{H}_{2} \mathrm{O}$ 系 - (本紙 投稿予定). 


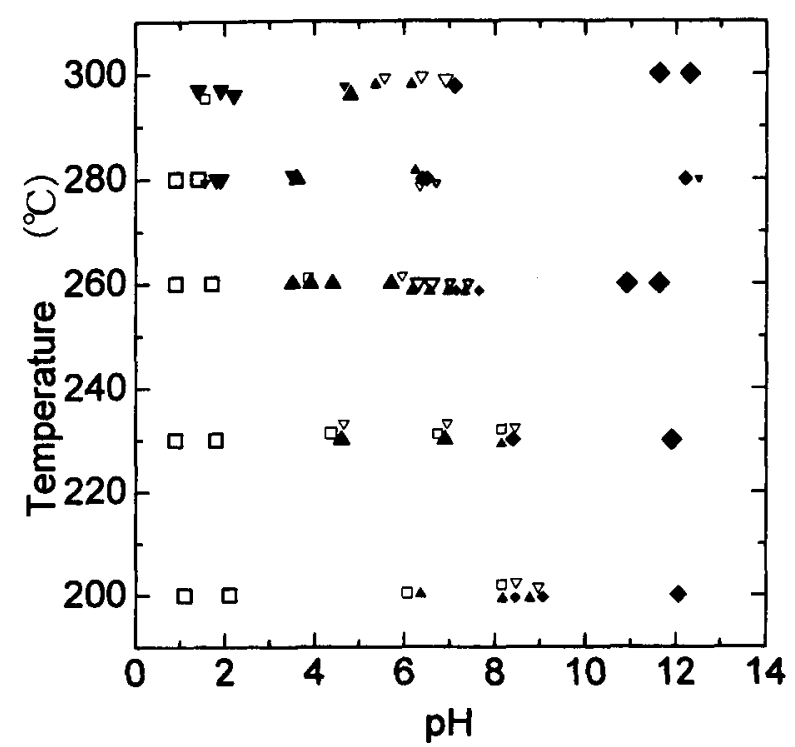

Fig.4 Formation diagram of the precipitate obtained in $\mathrm{BiO}\left(\mathrm{NO}_{3}\right)$ $\mathrm{KOH}-\mathrm{H}_{2} \mathrm{O}$ system at temperature of 200 to $300^{\circ} \mathrm{C}$. $\nabla$ : new compound "A" $\left(\mathrm{Bi}_{5}\left(\mathrm{NO}_{3}\right)_{2} \mathrm{O}_{6}(\mathrm{OH}), \nabla:\right.$ new compound "B" $\left(\mathrm{Bi}_{5}\left(\mathrm{NO}_{3}\right) \mathrm{O}_{6}(\mathrm{OH})_{2}\right), \diamond$ : new compound " $\mathrm{C}^{\prime \prime}\left(\mathrm{Bi}_{6}\left(\mathrm{NO}_{3}\right)_{3} \mathrm{O}_{2}(\mathrm{OH})_{3}\right)$, $\Delta$ : new compound " $\mathrm{E}^{\prime \prime}\left(\mathrm{Bi}_{6}\left(\mathrm{NO}_{3}\right)_{2} \mathrm{O}_{7}(\mathrm{OH})_{2}\right), \bullet: \alpha-\mathrm{Bi}_{2} \mathrm{O}_{3}$, $\square: \mathrm{Bi}_{6}\left(\mathrm{NO}_{3}\right)_{3} \mathrm{O}_{6}(\mathrm{OH})_{3}$.

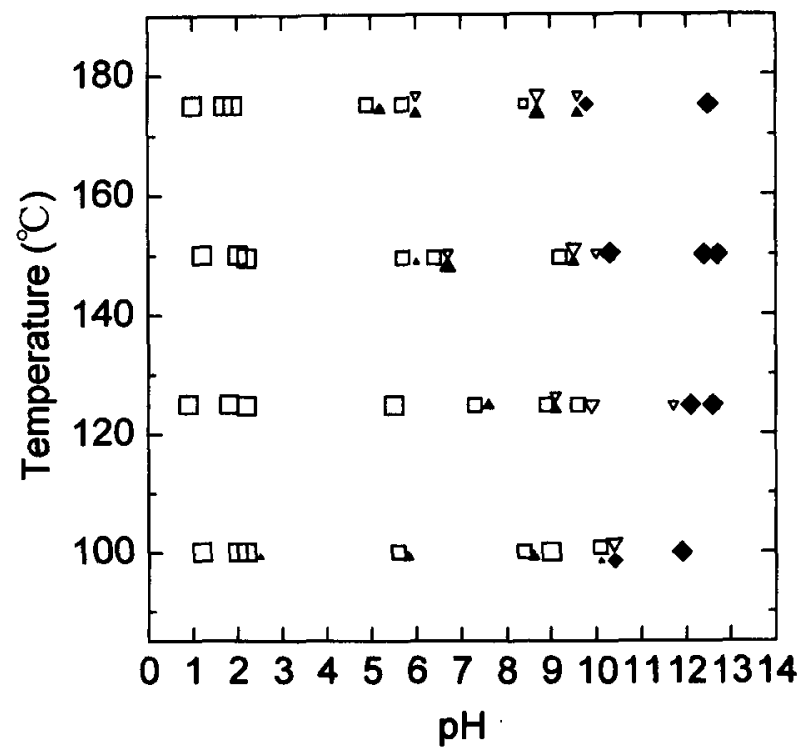

Fig.5 Formation diagram of the precipitate obtained in $\mathrm{BiO}\left(\mathrm{NO}_{3}\right)$ $\mathrm{KOH}-\mathrm{H}_{2} \mathrm{O}$ system at temperature of 100 to $180^{\circ} \mathrm{C}$. $\nabla:$ new compound "B" $\left(\mathrm{Bi}_{5}\left(\mathrm{NO}_{3}\right) \mathrm{O}_{6}(\mathrm{OH})_{2}\right), \Delta$ : new compound "E" $\left(\mathrm{Bi}_{6}\left(\mathrm{NO}_{3}\right)_{2} \mathrm{O}_{7}(\mathrm{OH})_{2}\right),: \alpha-\mathrm{Bi}_{2} \mathrm{O}_{3}, \square: \mathrm{Bi}_{6}\left(\mathrm{NO}_{3}\right)_{3} \mathrm{O}_{6}(\mathrm{OH})_{3}$.

\section{2 化学組成}

前述の分析方法により得られた各試料の成分をTable 1に示す. いずれの試料でもアルカリカチオンのK+は検出されなかった. また Bi および $\mathrm{NO}_{3}$ 以外の含有成分はOあるいは $\mathrm{OH}$ (あるい は $\left.\mathrm{H}_{2} \mathrm{O}\right)$ と考えられる.これらの観測されたテータと以下の 1. 〜3.の仮定の下に組成の決定を試みた. 1. 3.の仮定は行わ れた実験条件下ではいずれも十分に妥当なものと考えられる。

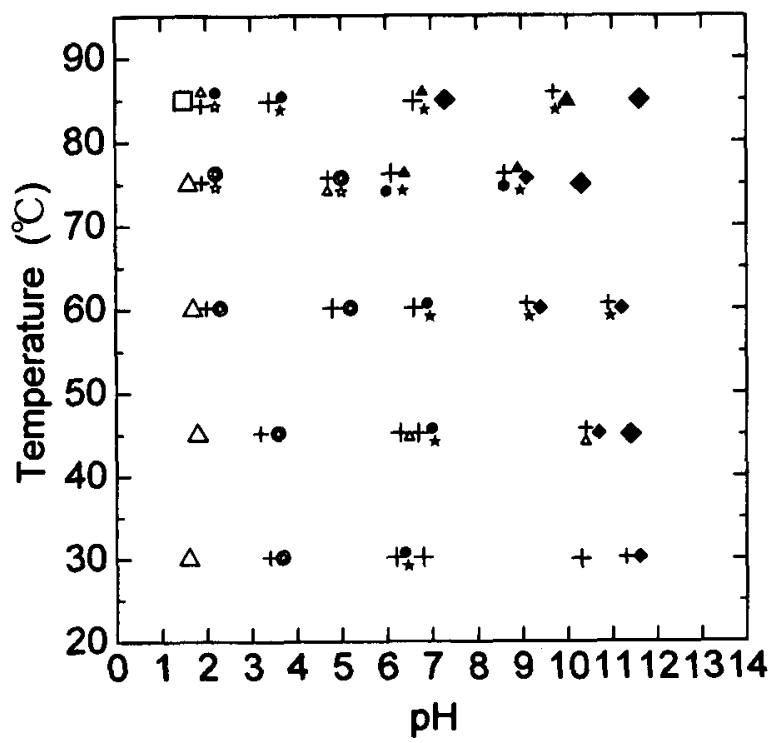

Fig.6 Formation diagram of the precipitate obtained in $\mathrm{BiO}\left(\mathrm{NO}_{3}\right)^{-}$ $\mathrm{KOH}-\mathrm{H}_{2} \mathrm{O}$ system at temperature of room temp. to $85^{\circ} \mathrm{C}$. $\Delta$ : new compound " $\mathrm{E}$ " $\left(\mathrm{Bi}_{6}\left(\mathrm{NO}_{3}\right)_{2} \mathrm{O}_{7}(\mathrm{OH})_{2}\right)$, : new compound " $F$ ", $\star$ : new compound " $\mathrm{G}$ ", (): new compound "H", $: \alpha-\mathrm{Bi}_{2} \mathrm{O}_{3}, \square: \mathrm{Bi}_{6}\left(\mathrm{NO}_{3}\right)_{3} \mathrm{O}_{6}(\mathrm{OH})_{3}, \triangle:\left[\mathrm{Bi}_{6} \mathrm{O}_{5}(\mathrm{OH})_{3}\right]$ $\left(\mathrm{NO}_{3}\right)_{5} \cdot 3 \mathrm{H}_{2} \mathrm{O}$.

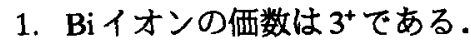

2. 化合物全体として電気的中性が満たされている.

3. アニオン或いはアニオン基としては $\mathrm{O}^{2-}, \mathrm{NO}_{3}^{-}, \mathrm{OH}^{-} か^{5}$ 存在している.

但し, $2(\mathrm{OH})^{-}$と $1 / 2 \mathrm{O}_{2}^{-}+\mathrm{H}_{2} \mathrm{O}$ は重量的にも電荷としても区別が つかないために便宜上 $\mathrm{OH}^{-} に$ 統一して表記する.このような 仮定の下では水溶液中で生成するビスマス塩基性硝酸塩複合 酸化物の組成は表記される。

$$
\mathrm{Bi}_{\mathrm{m}}\left(\mathrm{NO}_{3}\right)_{\mathrm{m}-\mathrm{y}} \mathrm{O}_{\mathrm{m}-\mathrm{x}}(\mathrm{OH})_{2 \mathrm{x}+\mathrm{y}} \quad \mathrm{m}, \mathrm{x}, \mathrm{y} ; \text { 整数 }(\mathrm{m} \geqq \mathrm{x}, \mathrm{m} \geqq \mathrm{y})
$$

ここで $\mathrm{m}, \mathrm{x}, \mathrm{y}$ を仮定してカチオン, アニオン, アニオン基の 相対的なモル比を計算し，実測值と良い一致を示した組成を もって各化合物の組成とした ${ }^{* 3}$.

Table 2 に $, \mathbf{x}, \mathrm{y}$ をパラメータとして計算した, 仮想的な組 成式の各成分の相対的な值を, Table 3には計算值と実測值との 比較により得られた各新規化合物のもつとも確からしい化学 組成式を示す，これらの結果新規化合物の組成はそれぞれ "A": $\left(\mathrm{Bi}_{5}\left(\mathrm{NO}_{3}\right)_{2} \mathrm{O}_{6}(\mathrm{OH})\right)$, "B": $\left(\mathrm{Bi}_{5}\left(\mathrm{NO}_{3}\right) \mathrm{O}_{6}(\mathrm{OH})_{2}\right)$, "C": $\left(\mathrm{Bi}_{6}\left(\mathrm{NO}_{3}\right)_{3} \mathrm{O}(\mathrm{OH})_{3}\right)$, "E": $\left(\mathrm{Bi}_{6}\left(\mathrm{NO}_{3}\right)_{2} \mathrm{O}_{2}\left(\mathrm{OH}_{2}\right)\right.$ と求められた.

3.3 合成条件と各相間の相対的な関係

Fig.7に温度を縦軸に添加 $\mathrm{KOH}$ 水溶液濃度を横軸にとり, 水

\footnotetext{
3)この方法による化学組成の決定はBiイオンの重量が他の成分に比較して大 きいためmの值を大きくとると限りなく実測されたモル比の組成に近つけ ることが可能である.しかしながら，mの值が大きくなることは結晶の単位 格子中のBiイオンの個数が增えることを意味しており，実際上はこの点か $5 \mathrm{~m}$ の值に上限が存在する.これを考虑して $\mathrm{m}=3 \sim 7$ の籍用を採用して いる.
} 
Table 1 The chemical analysis of the new compounds.

\begin{tabular}{|c|c|c|c|c|c|c|}
\hline \multirow{2}{*}{ compound } & \multicolumn{2}{|c|}{$\mathrm{Bi}$ content } & \multicolumn{2}{c|}{$\mathrm{NO}_{3}$ content } & \multicolumn{2}{c|}{ residual } \\
\cline { 2 - 7 } & wt\% & mole\% & wt\% & mole $\%$ & wt\% & mole\% \\
\hline $\mathrm{BiONO}_{3}$ & 72.0 & 34.4 & 19.1 & 30.8 & 8.1 & 34.8 \\
\hline $\mathrm{A}$ & 80.7 & 38.6 & 9.6 & 15.4 & 9.7 & 46.0 \\
\hline $\mathrm{B}$ & 86.1 & 41.2 & 3.4 & 5.5 & 10.6 & 53.3 \\
\hline $\mathrm{C}$ & 80.2 & 38.4 & 11.4 & 18.3 & 8.4 & 43.3 \\
\hline E & 82.3 & 39.4 & 8.3 & 13.3 & 9.4 & 47.7 \\
\hline
\end{tabular}

* $\mathrm{K}^{+}$is not detected.

Table 2 The ratio of the chemical component in the various hypothetic chemical formula.

\begin{tabular}{|c|c|c|c|c|c|c|c|c|}
\hline & \multirow[t]{2}{*}{ composition } & \multirow[t]{2}{*}{$\begin{array}{l}\text { Molecular } \\
\text { weight }\end{array}$} & \multicolumn{2}{|c|}{ Bi content } & \multicolumn{2}{|c|}{$\mathrm{NO}_{3}$ content } & \multicolumn{2}{|c|}{$\begin{array}{c}\text { Residual } \\
\left(\mathrm{H}_{2} \mathrm{O}, \mathrm{OH}, \mathrm{O}\right)\end{array}$} \\
\hline & & & wt $\%$ & mole $\%$ & $w t \%$ & mole $\%$ & wt $\%$ & mole $\%$ \\
\hline \multirow[t]{2}{*}{$\mathrm{m}=3$} & $\mathrm{Bi}_{3}\left(\mathrm{NO}_{3}\right) \mathrm{O}_{3}(\mathrm{OH})_{2}$ & 771.024 & 81.32 & 38.91 & 8.04 & 13.00 & 10.64 & 48.09 \\
\hline & $\mathrm{Bin}_{3}\left(\mathrm{NO}_{3}\right) \mathrm{O}_{4}$ & 753.008 & 83.27 & 39.84 & 8.20 & 13.22 & 8.53 & 46.94 \\
\hline \multirow[t]{3}{*}{$\mathrm{m}=4$} & $\mathrm{Bi}_{4}\left(\mathrm{NO}_{3}\right)_{2} \mathrm{O}_{5}$ & 1040.016 & 81.32 & 38.46 & 11.92 & 19.06 & 7.70 & 42.48 \\
\hline & $\mathrm{Bi}_{4}\left(\mathrm{NO}_{3}\right) \mathrm{O}_{4}(\mathrm{OH})_{3}$ & 1013.032 & 82.52 & 39.48 & 6.12 & 9.87 & 11.36 & 50.65 \\
\hline & $\mathrm{Bi}_{4}\left(\mathrm{NO}_{3}\right) \mathrm{O}_{6}(\mathrm{OH})$ & 995.016 & 84.02 & 40.20 & 6.13 & 9.89 & 9.85 & 49.91 \\
\hline \multirow[t]{5}{*}{$m=5$} & $\mathrm{Bi}_{5}\left(\mathrm{NO}_{3}\right)_{2} \mathrm{O}_{5}(\mathrm{OH})_{3}$ & 1300.04 & 80.38 & 38.46 & 9.54 & 15.39 & 10.08 & 46.15 \\
\hline & $\mathrm{Bi}_{5}\left(\mathrm{NO}_{3}\right)_{2} \mathrm{O}_{6}(\mathrm{OH})$ & 1282.024 & 81.51 & 39.00 & 9.67 & 15.59 & 8.82 & 45.41 \\
\hline & $\mathrm{Bi}_{5}\left(\mathrm{NO}_{3}\right) \mathrm{O}_{5}(\mathrm{OH})_{4}$ & 1255.04 & 83.26 & 39.84 & 4.94 & 8.00 & 11.80 & 52.16 \\
\hline & $\mathrm{Bi}_{5}\left(\mathrm{NO}_{3}\right) \mathrm{O}_{6}(\mathrm{OH})_{2}$ & 1237.024 & 84.47 & 40.42 & 5.01 & 8.08 & 10.52 & 51.50 \\
\hline & $\mathrm{Bi}_{6}\left(\mathrm{NO}_{3}\right) \mathrm{O}_{7}$ & 1219.008 & 85.73 & 41.02 & 5.09 & 8.21 & 9.18 & 50.77 \\
\hline \multirow[t]{7}{*}{$m=6$} & $\mathrm{Bi} 6\left(\mathrm{NO}_{3}\right)_{3} \mathrm{O}_{7}(\mathrm{OH})$ & 1569.032 & 79.92 & 38.24 & 11.86 & 19.13 & 8.82 & 42.63 \\
\hline & $\mathrm{Bi} 6\left(\mathrm{NO}_{3}\right)_{2} \mathrm{O}_{6}(\mathrm{OH})_{4}$ & 1542.048 & 81.32 & 38.91 & 8.04 & 13.00 & 10.64 & 48.09 \\
\hline & $\mathrm{Bi}_{6}\left(\mathrm{NO}_{3}\right) \mathrm{O}_{6}(\mathrm{OH})_{5}$ & 1497.048 & 83.76 & 40.01 & 4.14 & 6.68 & 12.10 & 53.31 \\
\hline & $\mathrm{Bi}_{6}\left(\mathrm{NO}_{3}\right)_{2} \mathrm{O}_{7}(\mathrm{OH})_{2}$ & 1524.032 & 82.28 & 39.37 & 8.14 & 13.13 & 9.58 & 47.50 \\
\hline & $\mathrm{Bi}_{6}\left(\mathrm{NO}_{3}\right)_{\mathrm{O}_{7}}(\mathrm{OH})_{3}$ & 1479.032 & 84.79 & 40.57 & 4.19 & 6.76 & 11.02 & 52.67 \\
\hline & $\mathrm{Bi}_{6}\left(\mathrm{NO}_{3}\right) \mathrm{O}_{8}(\mathrm{OH})$ & 1461.016 & 85.83 & 41.07 & 4.24 & 6.84 & 9.93 & 52.09 \\
\hline & $\mathrm{Bi}_{6}\left(\mathrm{NO}_{3}\right)_{2} \mathrm{O}_{8}$ & 1506.016 & 83.26 & 39.84 & 8.23 & 4.10 & 8.51 & 56.06 \\
\hline \multirow[t]{7}{*}{$\mathrm{m}=7$} & $\mathrm{Biz}\left(\mathrm{NO}_{3}\right)_{3} \mathrm{O}_{7}(\mathrm{OH})_{4}$ & 1819.056 & 80.43 & 38.48 & 10.23 & 16.50 & 9.34 & 45.02 \\
\hline & $\mathrm{Bi} 7\left(\mathrm{NO}_{3}\right)_{3} \mathrm{O}_{8}(\mathrm{OH})_{2}$ & 1811.04 & 80.78 & 38.65 & 10.27 & 16.56 & 8.95 & 44.79 \\
\hline & $\mathrm{Bi} 7\left(\mathrm{NO}_{3}\right)_{3} \mathrm{O}_{9}$ & 1793.024 & 81.59 & 39.04 & 10.37 & 16.72 & 8.04 & 44.24 \\
\hline & $\mathrm{Bi} 7\left(\mathrm{NO}_{3}\right)_{2} \mathrm{O}_{7}(\mathrm{OH})_{5}$ & 1836.064 & 79.68 & 38.12 & 6.75 & 10.89 & 13.57 & 50.99 \\
\hline & $\mathrm{Bi} 7\left(\mathrm{NO}_{3}\right)_{2} \mathrm{O}_{8}(\mathrm{OH})_{3}$ & 1732.024 & 84.46 & 40.41 & 7.16 & 11.55 & 8.38 & 48.04 \\
\hline & $\mathrm{Bi}_{7}\left(\mathrm{NO}_{3}\right)_{2} \mathrm{O}_{9}(\mathrm{OH})$ & 1748.024 & 81.81 & 39.14 & 7.09 & 11.43 & 11.10 & 49.43 \\
\hline & $\mathrm{Bi} 7\left(\mathrm{NO}_{3}\right) \mathrm{O}_{10}$ & 1685.008 & 86.82 & 41.54 & 3.68 & 5.93 & 9.50 & 52.53 \\
\hline
\end{tabular}


Table 3 The most probable chemical formulas of the new compounds.

\begin{tabular}{|c|c|c|}
\hline compound & chemical composition & Ratio of $\mathrm{Bi}$ to $\mathrm{NO}_{3}$ \\
\hline $\mathrm{A}$ & $\mathrm{Bi}_{5}\left(\mathrm{NO}_{3}\right)_{2} \mathrm{O}_{6}(\mathrm{OH})$ & $5: 2$ \\
\hline $\mathrm{B}$ & $\mathrm{Bi}_{5}\left(\mathrm{NO}_{3}\right)_{6}(\mathrm{OH})_{2}$ & $5: 1$ \\
\hline $\mathrm{C}$ & $\mathrm{Bi}_{6}\left(\mathrm{NO}_{3}\right)_{3} \mathrm{O}_{7}(\mathrm{OH})$ & $6: 3$ \\
\hline$E$ & $\mathrm{Bi}_{6}\left(\mathrm{NO}_{3}\right)_{2} \mathrm{O}_{7}(\mathrm{OH})_{2}$ & $6: 2$ \\
\hline
\end{tabular}

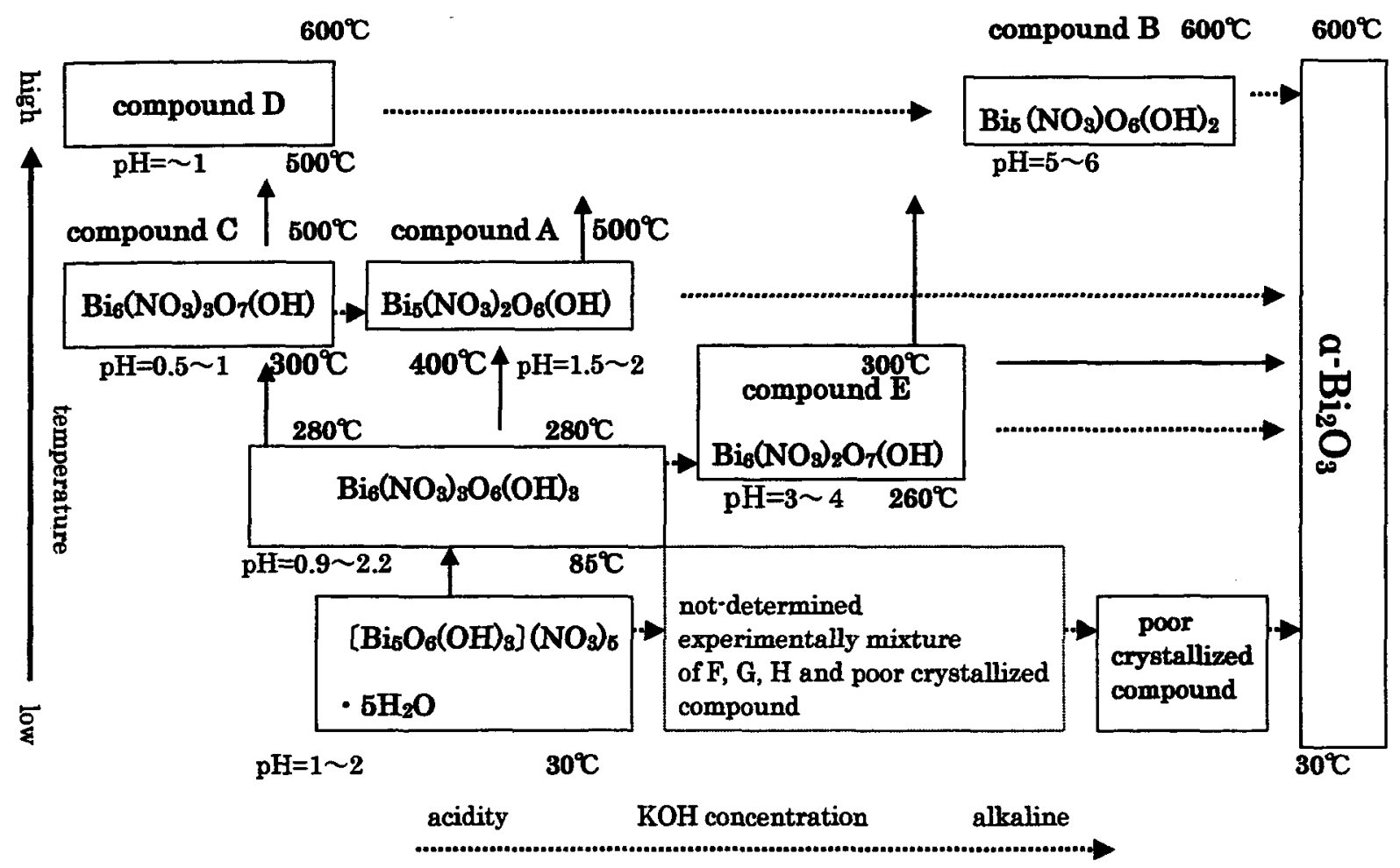

Fig.7 Schematic illustration of the consecutive change of products depending on temperature $(\uparrow)$ and/or $\mathrm{KOH}$ concentration $(\rightarrow)$.

溶液中で生成された化合物の相対的な位置関係を示している. この図が示しているように $\mathrm{BiO}\left(\mathrm{NO}_{3}\right)$ を出発原料として, 温度 とアルカリ添加比をパラメータとした反応では当初の組成式 の $\mathrm{Bi}_{\mathrm{m}}\left(\mathrm{NO}_{3}\right)_{\mathrm{m}-\mathrm{y}} \mathrm{O}_{\mathrm{m}-\mathrm{x}}(\mathrm{OH})_{2 \mathrm{x}+\mathrm{y}}(\mathrm{m}=1, \mathrm{x}=0, \mathrm{y}=0)$ 加温度を一定に 保ったままで $\mathrm{OH}^{-}$を增加させて行くと, 見かけ上では $\mathrm{NO}_{3}{ }^{-}$か $\mathrm{OH}^{-}$に置換する反応が起こりはじめ，更に $\mathrm{OH}^{-}$の增加ととも に $\mathrm{NO}_{3}{ }^{-}$の置換に加えて $2 \mathrm{OH}^{-}$が脱水して $1 / 2 \mathrm{O}_{2}{ }^{-}$と $\mathrm{H}_{2} \mathrm{O}$ となる 脱水反応が起こり最終的に溶液中で $\mathrm{OH}^{-}$が過剩になり水溶液 の $\mathrm{pH}$ がアルカリ性領域になると完全な脱 $\mathrm{NO}_{3}-$ と脱 $\mathrm{H}_{2} \mathrm{O}$ の反 応が起こり， $\alpha-\mathrm{Bi}_{2} \mathrm{O}_{3}$ が生成する. また一定のアルカリ添加比 で温度を上昇させると同様の㚆化が起こると考えられる. 最 終溶液の $\mathrm{pH}$ が酸性を示すアルカリ添加量の反応領域中では， 実験された温度条件下では $\alpha-\mathrm{Bi}_{2} \mathrm{O}_{3}$ までの完全な脱 $\mathrm{NO}_{3}{ }^{-}$およ
び脱 $\mathrm{H}_{2} \mathrm{O}$ は進行しなかった.ここに述べた過程はあくまでも 化学組成式の上から見た仮想的な反応であり, 実際に起こっ ている反応が出発原料の母塩の結晶格子が保たれたままでイ ンターカレーションーテインターカレーション反応によるも のか, あるいは溶解再析出反応によるものなのかは現在のと ころ不明である。

また $\mathrm{Bi}_{\mathrm{m}}\left(\mathrm{NO}_{3}\right)_{\mathrm{m}-\mathrm{y}} \mathrm{O}_{\mathrm{m}-\mathrm{x}}(\mathrm{OH})_{2 \mathrm{x}+\mathrm{y}}$ で示される仮想的な組成式の全 ての $\mathrm{m}, \mathrm{x}, \mathrm{y}$ について化合物が存在するのか, 存在するとすれ ば生成条件はどのようなものであるかなどについても不明で あり，後に残された問題と考えられる。

\section{4 結 論}

(1) $\mathrm{BiO}\left(\mathrm{NO}_{3}\right)$ と $\mathrm{KOH}$ 水溶液の組み合わせによる水熱反応によ 
り, 室温〜 $600^{\circ} \mathrm{C}$ 反応温度範团の生成図を作成し, XRD パターンより7種類の新規硝酸ビスマス塩基性複合酸化物 が生成することを見い出した。

(2) 単離した新規硝酸ヒスマス塩基性複合酸化物の4種類につ いて組成分析の結果,もっとも確からしい化学組成はそれ それ, $\mathrm{Bi}_{5}\left(\mathrm{NO}_{3}\right)_{2} \mathrm{O}_{6}(\mathrm{OH}), \mathrm{Bi}_{5}\left(\mathrm{NO}_{3}\right) \mathrm{O}_{6}(\mathrm{OH})_{2}, \mathrm{Bi}_{6}\left(\mathrm{NO}_{3}\right)_{3} \mathrm{O}_{7}(\mathrm{OH})$, $\mathrm{Bi}_{6}\left(\mathrm{NO}_{3}\right)_{2} \mathrm{O}_{7}(\mathrm{OH})_{2}$ と推定された.

(3) 硝酸ビスマス塩基性複合酸化物の一般式を $\mathrm{Bi}_{\mathrm{m}}\left(\mathrm{NO}_{3}\right)_{\mathrm{m}-\mathrm{y}} \mathrm{O}_{\mathrm{m}-\mathrm{x}}$ $(\mathrm{OH})_{2 x+y}$ と表わすと一定温度での溶液の $\mathrm{pH}$ 増大は, 見か け上 $\mathrm{NO}_{3}^{-}$と $\mathrm{OH}^{-}$の置換, $2(\mathrm{OH}) \rightarrow 1 / 2 \mathrm{O}_{2}+\mathrm{H}_{2} \mathrm{O}$ による脱水 反応を連続して引き起こすのではないかと考えられる.ま た一定 $\mathrm{pH}$ 值下での温度の上昇も同様の効果を引き起こす と考えられる.今回の実験条件下では $\mathrm{pH}$ が中性以上では 完全に脱 $\mathrm{NO}_{3}^{-}$および脱 $\mathrm{H}_{2} \mathrm{O}$ により $\alpha-\mathrm{Bi}_{2} \mathrm{O}_{3}$ の生成が認め られた。

值が酸性 $\mathrm{pH}$ 領域では $600^{\circ} \mathrm{C}$ の温度まではまだ $\alpha-\mathrm{Bi}_{2} \mathrm{O}_{3}$ の 生成は認められなかった.

\section{文献}

1) P.S.Anand and D.R.Baxi: "Preparation and Ion-Exchange
Properties of Basic Bismuth Nitrate", Indian J. Technol., 16(1978) 198-200.

2) P.Taylar, D.D.Woodand and V.J.Lopata: "SOLIDIFICATION OF DISSOLVED AQUEOUS IODIDE BY REACTION WITH $\alpha-\mathrm{Bi}_{2} \mathrm{O}_{3}$ POWDER TO FORM $\left.\alpha-\mathrm{Bi}_{5} \mathrm{O}_{7}\right]^{\prime \prime}$, Atomic Energy of Canada Limited Report, AECL-9554, (1988).

3) H.Kodama: "Solidification of Iodide Ion by Reaction with $\mathrm{Bi}_{2} \mathrm{O}_{3}$ ", Bull. Chem. Soc. Jpn., 65(1992)3011-3014.

4) H.Kodama: "THE REMOVAL OF IODIDE AND CHLORIDE IONS FROM SOLUTION USING BISMUTH OXIDE NITRATE", Advances in Ion Exchange for Industry and Research, P.A.Williams and A.Dyer eds., The Royal Society of Chemistry, (1999)191-198.

5) N.kabay and H.Kodama: "ION EXCHANGE PROPERTIES OF $\mathrm{BiO}\left(\mathrm{NO}_{3}\right) \cdot 0.5 \mathrm{H}_{2} \mathrm{O}$ TOWARDS FLUORIDE IONS", Solvent Extr. Ion Exch., 18(3) (2000)583-603.

6) 清井昭彦: "ソフトプロセスによるBi 複合酸化物合成の試 み", 京大院 人環修士論文, (1999).

7) H.Kodama: "Synthesis of a New Compound, $\mathrm{Bi}_{5} \mathrm{O}_{7} \mathrm{NO}_{3}$, by Thermal Decomposition", J. Solid. State Chem., 112(1994)27-30. 